An early miniature copy of the choir vault of Wells Cathedral at Irnham, Lincolnshire

\title{
Paul Binski
}

The parish church of St Andrew at Irnham in Lincolnshire is closely associated with the Luttrell family, two of whose members, Sir Geoffrey Luttrell (d. 1345) and his wife Agnes, née Sutton (d. 1340), commissioned the celebrated Psalter, now BL Add. MS 42130. ${ }^{1}$ It possesses an enigmatic and elaborately carved stone monument (Fig. 1) bearing the arms of Geoffrey and Agnes. This structure was inserted c. 1858 into the east wall of the north chancel aisle where it still stands, but was originally almost certainly a freestanding monument beneath the easternmost arcade arch separating the aisle from the chancel (Fig. 2). It awaits a full physical investigation, and to date there has been no agreement as to what its original function might have been. ${ }^{2}$ This short intervention on the Irnham monument will first consider its form and function, because this may have some bearing on this paper's main point, which is that the miniature vault within the superstructure of the object is a copy of the high vault of the choir of Wells Cathedral.

\section{Form and function of the Irnham monument}

The structure is divided into three niched bays consisting of a plinth and stone chest beneath a canopy raised on four buttressed and pinnacled piers, with intervening nodding ogee canopies beneath gables, and an undulating crenellated parapet with intervening miniature gabled and crenellated polygonal canopies. Shields of Luttrell (proper right) and Sutton (proper left) and carved in the spandrels, and the finials of the nodding arches support, to the left, a Crucifixion and at centre a Virgin and Child (Figs. 3, 4); the right finial is plain. The flanks as well as the top front face are carved with very 
ornate foliage and pierced work (Fig. 5), the flanks bearing ogival reticulated tracery covered in rose and oak trellising. Traces of small, now struck-away, kneeling figures are to be found against the exterior of the reticulated areas of the carved flanks on the present north and south sides, that on the north retaining the silhouette of a kneeling figure, probably a woman with a belted tunic raising her arms in prayer (Fig. 6). There are numerous small carved crenellations, heads and baboons, including an inverted dog-mask with ears folding upwards in the southern bay. The arms of Geoffrey and Agnes are located in the same relative position as the images of the donors on the magnificent piscina at Troyes (Champagne), the piscina being in the vanguard of the type of showy sacramental furnishing typical of eastern England in the $14^{\text {th }}$ century. ${ }^{3}$ It may have been from an object such as that at Troyes that the Irnham monument derived its polygonal crenellated canopies. It has a plan measuring $2.41 \times 0.65 \mathrm{~m}$. But an inspection of its flanks (Fig. 5) shows that a proportion of the monument may be submerged in the rendering of the east wall of the north aisle. Its original depth, extrapolated from the gables on the flanks (on the reasonable assumption that the flanks were designed symmetrically), was nearer $1.3 \mathrm{~m}$, and the likelihood is that the structure was originally decorated in the round. The easternmost north chancel arcade from which it was removed is about three metres wide and would comfortably have accommodated it. ${ }^{4}$ The orientation of the two lost kneeling figures presently facing west on the flanks indicates that the monument's visible face must originally have looked south, as no patronal, angelic or votive image would turn its back to the chancel. If so it must have been free-standing, orientated east-west and, if it had no backing wall, illuminated both from north and south with the arms of Luttrell to the west and Sutton to the east.

The Irnham monument has been drawn into studies of the development of Easter Sepulchres and related furnishings of the sort at Heckington and 
Navenby (Lincs.), and Hawton (Notts.). ${ }^{5}$ Two things argue against an identification of it as an Easter Sepulchre. The first is that freestanding stone Easter Sepulchres are unknown in eastern England at this time. The second is that the extant imagery of a Crucifixion and a Virgin and Child on the finials (Figs 3,4) is not the iconography of Eastertide. In this region at this date a carved Easter Sepulchre with any claim to comprehensiveness would bear images of the risen Christ, the Three Maries and the sleeping soldiers. ${ }^{6} \mathrm{~A}$ Crucifixion and a Virgin Mary might perhaps point to some other eucharistic function, and it should be noted that Sir Geoffrey took care in his will to make provision for images of the Virgin Mary at the cathedrals of St Paul's, Canterbury and York, and also Walsingham ${ }^{7}$. But the chancel possesses a $14^{\text {th }}$-century aumbry to the north of the high altar (Fig. 2, right) which suggests that the monument, itself without any provision for security, was not a location for reserving the Sacrament. ${ }^{8}$ Sir Geoffrey Luttrell's will stipulated his burial in the church's chancel before the high altar dedicated to St Andrew. 9 The form of the structure is not instantly reminiscent of contemporary tomb design, but the possibility exists that it was the tomb of either Geoffrey or Agnes Luttrell (or both) as the heraldry might indicate, its form following high-status three-bay canopied monuments such as those at Hereford, Westminster, Winchelsea or Gloucester but suitably lowered in height to fit under a parish church arcade to the point where it resembles a shrine base. ${ }^{10}$ The dimensions as fully recovered $(2.4 \times 1.3 \mathrm{~m})$ could be consistent with a tomb with a marble base and an effigy or more probably, given the intrusive three-sided interior faces of the buttress shafts, a brass. ${ }^{11}$

\section{The vault}

The general form of the structure is not its only unusual feature. Another is the miniature vault carved within the upper niched space (Fig. 7). The structure's identification with the Luttrells and its probable original function 
and location are germane to the discussion of its inner vault. As a freestanding structure lit both from north and south the vault would have been fully visible. It might be added, tentatively, that the open-work character of the upper stage could be very effectively illuminated from within. The vault is in effect one-half of a barrel vault running the full length of monument and rising towards the rear of the object where it disappears into the modern rendering of the east wall (Fig. 8). Its rib-pattern consists of tracery in a regular pattern of linked rectangles and hexagons, much of which is pierced in keeping with the reticulated texture of the monument's exterior. In overall form and pattern the design is clearly a miniature version of the high vault of the choir of Wells Cathedral (Fig. 9). The rib pattern has been stretched by a factor of about fifty per cent in such a way that the original square and hexagonal components of the great vault appear strikingly lengthened, the boss-work linking the hexagons and filling the squares appearing disproportionately large. The rib pattern includes the bisection of the hexagonal units by the transverse ribs of the Wells vault. The cutting through of some of the webbing of the miniature vault underlines the (postmedieval) term 'net' for such vaults. While regular patterns of this type are known in other media, for instance in the ultimately metalwork-derived geometrical borders and line-endings of the Luttrell Psalter itself, the case for the Wells genesis of this vault seems firm despite the absence of tiny details such as the cusped squares of the original pattern.

Assuming a date around 1340 or the 1340 s for the Irnham monument, as its style and heraldry suggest, its vault appears to be the only net vault in this region of England, in effect an outlier of a vault type developed in the West of England, at Bristol, Wells, Ottery St Mary, Exeter, Tewkesbury and Gloucester. The original at Wells was raised by William Joy (first recorded in the works at Wells in 1329) in the 1330s prior to the insertion of the choir's 
clearstory glazing. ${ }^{12}$ This must help provide a terminus post quem for the work at Irnham which probably followed quickly. As Henning Bock was amongst the first to note, an interest in 'unorthodox' vault types was manifest in Lincolnshire and Nottinghamshire in the form of the flying ribs found within the Easter Sepulchre (c. 1300) of Lincoln Cathedral and the pulpitum at Southwell Minster (1330s). ${ }^{13}$ Generally at this time, however, English microvaulting took the form of quadripartite or tierceron vaulting with ridge and transverse ribbing, as for instance on the tomb of Bishop Marcia at Wells and the tomb of Pope John XXII at Avignon. Obvious imitations on a miniature scale of specific high vaults are a rarity at this date. A miniature net vault which resembles the transept's high vault can be found on the underside of the so-called 'Prentice's Bracket' in the south transept at Gloucester Cathedral, probably of the 1330s. ${ }^{14}$ The painted conoidal vaults of the canopy of the tomb of Hugh le Despencer at Tewkesbury Abbey, raised in the 1350s, respond to the earliest fan vaulting in the cloister at Gloucester of that decade. 15 That larger-scale models were consulted in all these cases seems certain, and should rule out any idea that in this regard at least, micro-architecture was innovative.

At Wells the superlative richness of the high vault is supported on an elevation that matches it in elaboration. But why at Irnham a specifically western English form of vault should have been shrunk, tugged around and inserted into the context of a no less richly-worked monument conforming more to regional Lincolnshire practices is not at first apparent. One answer to this might be to see Irnham as a minor manifestation of the admiration of the $14^{\text {th }}$-century work at Wells apparent as far afield as eastern Iberia (Huesca) and Bohemia (Prague). ${ }^{16}$ But another solution is provided by the Luttrell family itself. The Luttrell estates were in Yorkshire, Lincolnshire, Nottinghamshire and Leicestershire, but also in Somerset: Andrew Luttrell (d. 
1265) had made the Somerset estates near East Quantockshead over to his second son, Alexander, while himself settling at Irnham. ${ }^{17}$ In effect from 1253 there was a Somerset as well as an East Midlands branch of the family, Alexander Luttrell being the grandfather of the Geoffrey Luttrell (III) who commissioned the great Psalter. The Somerset estates were within the diocese of Wells. It follows that the Irnham copy of the vault at Wells could have made some sort of allusion to the feudal 'reach' of the Luttrell family itself, or, more hypothetically, arose because the Somerset Luttrells had in some way been involved in the patronage of the choir vault in the first place and took some pride in the fact. For this last there is no evidence, though a Luttrell presence was apparent in the $15^{\text {th }}$-century heraldic glass of the cathedral. ${ }^{18}$

If this is so, the Irnham vault may tell us something new about the genealogy, as it were the blood-line, of certain types of architectural commission: that family links counted in the cross-regional dissemination of specific details of style. The citation of a particularly magnificent presbytery vault, with all the resonances of eucharistic dignity that such a vault might convey, illuminates both dynastic ambition and the sacramental character of such highly-wrought ecclesiastical furnishings. Genealogy aside, the Luttrell monument and its vault also allow us to stress that it was characteristic of this most inventive period of English art that generic distinctions were frequently blurred by formal innovation and functional and stylistic cross-fertilization. The Irnham monument may very well be a Luttrell tomb; but we cannot say categorically whether it had one function, or several. Whatever it was intended to do, it testifies to the remarkable innovations in vault design for which the English seem to have been particularly noted at this time, and in such a way as to make the more distant Luttrell family branch in the West 'present' in architectural guise. 


\section{Captions}

1 Irnham Parish Church, Lincs., Luttrell monument at east end of north chancel aisle (author)

2 Irnham Parish Church, chancel and north aisle from south west (author)

3 Irnham Parish Church, Luttrell monument, Crucifixion on finial (Julian Luxford)

4 Irnham Parish Church, Luttrell monument, Virgin and Child on finial (Julian Luxford)

5 Irnham Parish Church, Luttrell monument from north (author)

6 Irnham Parish Church, detail of Fig. 5 showing silhouette of lost kneeling figure (author)

7 Irnham Parish Church, Luttrell monument, canopy vault from below (author)

8 Irnham Parish Church, Luttrell monument, canopy vault viewed longitudinally from south (Julian Luxford)

9 Wells Cathedral choir vault (author) 


\section{NOTES}

${ }^{1}$ The best concise study of the Luttrells in question is J. Backhouse, The Luttrell Psalter, The British Library (London 1989); see also M. Camille, Mirror in Parchment. The Luttrell Psalter and the making of medieval England (London 1998).

2 It appears from visual inspection by the author together with Dr Julian Luxford - to whom the author is indebted for his assistance, discussion and suggestions - that the stonework of the base and four buttresses has been renewed at least to the level of the chest and, in the case of the southernmost two buttresses, to the first stage of gablets. The chest consists of a thick horizontal slab of dark fossiliferous limestone set on vertical slabs of the same material, which may also be wholly or partly replacements. As noted in the main text, below, about half the monument is buried in the cement rendering of the present east wall, and it is unclear what, if anything, could survive of the opposite main face, if it had one. For discussions see E. Woolley, 'Some Nottinghamshire and Lincolnshire Easter Sepulchres', Transactions of the Thoroton Society, 28 (1924), 69-72; E. Woolley, 'Irnham, Lincolnshire, and Hawton, Nottinghamshire', Journal of the British Archaeological Association, n.s. 35 (1929), 208-46. The monument is discussed briefly but usefully by V. Sekules, 'The Tomb of Christ at Lincoln and the development of the Sacrament Shrine: Easter Sepulchres reconsidered', in Medieval Art and Architecture at Lincoln Cathedral (British Archaeological Association Conference Transactions, 8), 1986, 118-31, 126 n. 3; it is the subject of a catalogue entry in P. Sheingorn, The Easter Sepulchre in England. Early Drama, Art and Music Reference Series, 5 (Kalamazoo 1989), 207; it is also discussed by R. Marks, 'Sir Geoffrey Luttrell and some companions: images of chivalry c. 1320-50', Wiener Jahrbuch für Kunstgeschichte, 46-47 (1993-94), 343-55, at 348 n. 24, and by Camille (as n. 1), 132-5. N. Coldstream, The Decorated Style: Architecture and Ornament, 1240-1360 
(London 1994), 157, calls it 'the tomb of Sir Geoffrey Luttrell'. The discussion by R. K. Emmerson and P. J. P. Goldberg, “The Lord Geoffrey had me made': Lordship and labour in the Luttrell Psalter' in The Problem of Labour in Fourteenth-Century England, ed. J. Bothwell, P. J. P. Goldberg and W. M. Ormrod (York 2000), 43-63, at 51-52 n. 25 is characteristic of scholarly indeterminacy on its function. It may be the stone monument recorded in his notes on the church by Francis Thynne as being 'iuxta capella in cancello', moved to its present location around 1858, see Sekules (as in n. 2), 126 n. 3.

${ }^{3}$ For the English liturgical affiliations of Saint-Urbain's sedilia and a brief discussion of Irnham see P. Binski, Gothic Wonder: Art, Artifice and the Decorated Style 1290-1350 (New Haven and London 2014), 152-3.

${ }^{4}$ The high altar steps and most of the chancel paving have been renewed, but the bay in question has in its paving a medieval stone altar-table with five consecration crosses. The altar to which it belonged was probably not that of the high altar, but could have been that at the east end of the north aisle taken down at the Reformation and probably inserted into the paving below. If so, in c. 1858 the monument was removed, the altar-table was lifted, and the location of the two exchanged.

5 Sekules (as in n. 2) has set out the evidence for eastern English sacramental furnishing and the cult of Corpus Christi.

${ }^{6}$ See Sekules (as in n. 2), 123 and the discussion at large in Sheingorn (as in n. 2).

7 The will and its codicil are printed conveniently with a translation in E. Millar, The Luttrell Psalter (London 1932), 52-6 for a transcription, at 55, 56.

8 Further useful discussions are in F. Bond, The Chancel of English Churches (Oxford 1916), 204-41 for aumbries, sacrament houses and Easter Sepulchres, also J. Kroesen and R. Steensma, The Interior of the Medieval Village Church (2 $2^{\text {nd }}$ edn.) (Leuven 2012), 107-37, 285-99; for sacrament houses see the fundamental 
study by A. Timmermann, Real Presence: Sacrament Houses and the Body of Christ, c.1270-1600 (Turnhout 2009).

9 Millar (as in n. 7), at 52: 'In primis lego... corpus meum ad sepelliendum in cancello ecclesie de Irnham coram magno altari beati Andree apostoli'. The will further specifies that 500 marks were to support twenty chaplains saying mass for his soul for five years after his death in 1345 .

10 As noted Marks (as in n. 2), at 348 n. 24

11 Given the cross-generational preference for brasses in certain families such as the D'Abernons and Cobhams (see for instance N. Saul, Death, Art, and Memory in Medieval England: the Cobham family and their monuments (Oxford 2001)), the choice by Geoffrey Luttrell's heir Andrew Luttrell (d. 1390) of a very fine London-made brass, set in the north aisle to the west of the monument under discussion (illustrated Camille, as in n. 1, ill. 46) may be significant.

12 The most useful guides to the building chronology of the new choir and presbytery of Wells including bibliographies are P. Draper, 'The sequence and dating of the Decorated Work at Wells', in Medieval Art and Architecture at Wells and Glastonbury (British Archaeological Association Conference Transactions, 4), 1981, 18-29, from 21, and T. Ayers, The Medieval Stained Glass of Wells Cathedral (CVMA Great Britain, 4), 2 vols (Oxford 2004), vol. 1, 137-40, 339. Net vaults are discussed seminally by H. Bock, Der Decorated Style. Untersuchungen zur englischen Kathedralarchitektur der ersten Hälfte des 14. Jahrhunderts, Heidelberg 1962, 56-67, and also by P. Crossley, 'Wells, the West Country, and Central European Late Gothic', in Medieval Art and Architecture at Wells and Glastonbury. British Archaeological Association Conference Transactions, 4 (1981), 81-109 and 'Peter Parler and England; a problem revisited', WallrafRichartz-Jahrbuch, 64 (2003), 53-82, 61-69. 
13 H. Bock, ‘Der Beginn spätgotischer Architektur in Prag (Peter Parler), und die Beziehungen zu England', Wallraf-Richartz Jahrbuch, 23 (1961), 191-210 at 207.

14 P. Binski, 'The 'Prentice's Bracket' at Gloucester Cathedral', Journal of the British Archaeological Association, 167, 2014, 124-132, fig. 4.

15 R. K. Morris, 'The Gothic Church: vaulting and carpentry', in Tewkesbury Abbey. History, Art and Architecture, ed. R. K. Morris and R. Shoesmith (Almeley 2007), 131-42, at 135 and fig. 11.7. The contrary is implied, in regard to Tewkesbury, by W. Leedy, Fan Vaulting: a study of form, technology, and meaning (London 1980), 3, 5, 8, based upon an unusually late dating of the first cloister vaults at Gloucester.

16 I cite the plan and micro-vaulting of the canopy of the image of the Virgin Mary on the tympanum of the west Apostle-portal of the cathedral of Huesca (where a master called Guillermo Inglés is recorded in 1338) reminiscent of the plan (though not the vault configuration) of the remodelled east end of Wells, see A. Z. Catalán, J. I. Fernández, ‘Materiales, técnicas y significados en torno a la arquitectura de la Corona de Aragón en tiempos del Compromiso de Caspe (1410-1412)', Artigrama, 29 (2011), 21-102 at 39 and fig. 1.3. The detailing of the window apertures of the tower adjoining the Apostle portal at Huesca also suggests familiarity with older English and possibly West Country architecture. The case for West Country (and other) studies by Peter Parler for Prague cathedral is set out anew by C. Wilson, 'Why did Peter Parler come to England?', in Architecture, Liturgy and Identity: Liber amicorum Paul Crossley, ed. Z. Opačić and A. Timmermann (Turnhout 2011), 89-109.

${ }^{17}$ Backhouse (as in n. 1), 16; and see Camille (as in n. 1), family tree at 94.

${ }_{18}$ Ayers (as in n. 12), vol. 2, 571-2 (arms of the Luttrells of Dunster Castle). 